\title{
Cytofluorometrical Determination of the DNA Contents of Bacteroids and Corresponding Broth-cultured Rhizobium Bacteria
}

\author{
By T. BISSELING, R. C. VAN DEN BOS AND A. VAN KAMMEN \\ Department of Molecular Biology, Agricultural University, Wageningen, \\ The Netherlands \\ AND M. VAN DER PLOEG AND P. VAN DUIJN \\ Department of Histochemistry and Cytochemistry, University of Leiden, \\ Leiden, The Netherlands
}

AND A. HOUWERS

Department of Microbiology, Agricultural University, Wageningen

(Received I February 1977)

\begin{abstract}
DNA contents of different species of broth-cultured Rhizobium bacteria and bacteroids from root nodules were determined by cytofluorometry. In almost all species bacteroids appeared to contain more DNA than the corresponding bacteria. A correlation was found between the DNA content and size of the bacteroid, the latter being influenced by the host plant.
\end{abstract}

\section{INTRODUCTION}

Rhizobium bacteria are capable of infecting legume roots and inducing the formation of root nodules (Bergersen, 1974). Within these root nodules the bacteria penetrate into the plant cells and most of them are transformed into so-called bacteroids in which the nitrogenase system is expressed. During the transformation into bacteroids, profound physiological and biochemical changes occur in the bacterial cell. The cells increase in size and become incapable of further multiplication. The transformation appears to be irreversible, since transformation of bacteroids into multiplying bacteria has not been observed (Bergersen, 1974). The loss in reproductive capacity might be due to a change in the quantity or quality of the DNA in the bacterial cell.

The DNA content of Rhizobium bacteroids has been a controversial matter in some publications. In work on Rhizobium japonicum (Bergersen, 1958), Rhizobium lupini (Dilworth \& Williams, 1967) and rhizobia associated with Lotus species (Sutton, 1974), the same amount or considerably less DNA per cell was found after bacteroid formation. However, Reijnders et al. (1975) found an appreciable increase in DNA content per cell in bacteroids of $R$. leguminosarum compared with broth-cultured bacteria. We now report the results of cytofluorometrical measurements on Feulgen-stained preparations of different Rhizobium species in the bacterial and the bacteroid forms. In contrast to other reports (Bergersen, 1958; Dilworth \& Williams, 1967; Sutton, 1974), we find that in most species investigated the bacteroids contain more DNA per cell than the corresponding bacteria.

We adopted a cytofluorometrical method (Böhm \& Sandritter, 1975; Prenna, Leiva \& Mazzini, I974; Bosman, 1976) for these measurements because the commonly used diphenylamine reaction (Burton, 1968) has several disadvantages. First, counting the bacteroid cells may be prone to errors due to their aggregation and lysis. Second, chemical analysis 
only gives information about the total amount of DNA in the sample, and thus the result may be influenced by contaminating DNA of non-rhizobial origin. Finally, only the mean DNA content per cell can be determined by the diphenylamine reaction and differences in DNA content between individual cells do not become evident. The cytofluorometrical method is rapid and quite simple and provides reliable results when performed under standardized conditions, while overcoming the disadvantages of the chemical method.

\section{METHODS}

Preparation of Rhizobium bacteria and bacteroids. Broth-cultured bacteria were isolated by centrifuging just after they had reached the stationary phase of growth. Bacteroids from 3- to 4-week-old pea plants were isolated as described by Reijnders et al. (I975), except that the KCl-DOC treatment was omitted.

Feulgen staining. Bacteria or purified bacteroids were suspended in distilled water and streaked on a microscope slide. The preparations were fixed and stained as described by van der Ploeg, van Duijn \& Ploem (1974). Hydrolysis was done in $5 \mathrm{M}-\mathrm{HCl}$ for $\mathrm{I} \mathrm{h}$ at room temperature. The preparations were stained in Schiff's reagent prepared from pararosanilin (Chroma, 'Acridinfrei', Stuttgart, G.F.R.) according to Graumann (1953).

Microfluorometrical DNA measurements. Microfluorometry of the Feulgen-stained preparations was done with an MPV II ( Leitz, Wetzlar, G.F.R.) (Böhm \& Sandritter, I975; van der Ploeg et al., 1977). The photomultiplier was an EMI $955^{8}$ with a S-20 cathode (EMI Electronic, Hayes, Middlesex), operated on a stabilized high-voltage supply (Knott Elektronik, Münich, G.F.R.), type MFLK BN S/N 396. Photometric readings were taken using epi-illumination from a $\mathrm{HBO} \mathrm{IOO}$ (Osram, Berlin, G.F.R.) high-pressure mercury arc which was operated on a highly stabilized direct current (Leitz power supply no. 500175). In the excitation light beam, a BG 38 (Leitz, $4 \mathrm{~mm}$ ) and a Calflex (Balzers, Lichtenstein) infrared reflecting filter were inserted. In the vertical illuminator, a dichroic mirror no. $4(\lambda \mathrm{H} \mathrm{580})$ in combination with a $\mathrm{K} 590$ (Leitz) barrier filter were used, an extra barrier filter $\mathrm{K} 590$ being applied in the slit above the vertical illumination.

The MPV II allows simultaneous observation of the object and the image of the measuring diaphragm. Under Koehler illumination conditions the measuring diaphragm was adjusted over the illuminated object. This measuring diaphragm was only slightly larger than the object and its size was not changed during the measurements. The Feulgen stain is sensitive to photo-decomposition and the amount of fluorescence emission diminishes during the measurement (about $10 \%$ decrease in $15 \mathrm{~s}$ ). Thus, in order to illuminate as small a portion of the preparation as possible, the field diaphragm of the Leitz MPV was set only slightly larger than the measuring diaphragm. The readings of the photomultiplier were shown on a digital voltmeter and were taken for each measurement after exactly $15 \mathrm{~s}$ of illumination of the object. Immediately afterwards, the background fluorescence in the vicinity was measured and used for correction of the measured cell fluorescence. A correction was also made for free aldehyde groups present in the cell, which might bind the dye irrespective of the acid hydrolysis. For this, non-hydrolysed cells were stained and fluorescence emission was measured in an identical manner and subtracted from the emission obtained in hydrolysed preparations.

The free aldehyde groups generated by the hydrolysis of DNA to apurinic acid are stained in such a way that the amount of Feulgen dye is directly proportional to the original quantity of DNA (Prenna et al., I974; Duijndam, 1975). The fluorescence emission depends on the intensity of the light source which may vary slightly from day to day, even though a highly stabilized lamp was used. Therefore in each series of measurements, readings were taken of a standard with known DNA content in order to take account of this effect. The staining procedure was always performed under strictly controlled conditions and preparations to be compared were always stained at one time.

Human metaphase chromosomes prepared according to Bosman et al. (1975) were used as the standard. From the known DNA content $\left(100 \times 10^{-15} \mathrm{~g}\right.$ ) of chromosome number 2I of the $\mathrm{G}$ group (Mendelsohn \& Mayall, 1974; Bosman et al., 1977) the DNA contents of bacteria and bacteroids were calculated, assuming a linear relationship between the fluorescence value and DNA content (Prenna et al., 1974).

\section{RESULTS AND DISCUSSION}

\section{Measurement of the DNA content of $R$. leguminosarum bacteria and bacteroids}

The DNA contents of $R$. leguminosarum strain PRE bacteria and bacteroids were measured to compare them with the results of Reijnders et al. (1975). The fluorescence emission values of stationary phase bacteria and of bacteroids from the root nodules of $2 \mathrm{I}$-day-old pea 
Table I. Cytofluorometrical measurement of the mean DNA content in bacteria and bacteroids of $R$. leguminosarum strain PRE

Fluorescence emission values (arbitrary units)

\begin{tabular}{|c|c|c|c|c|}
\hline Sample & Feulgen-stained & $\begin{array}{c}\text { Non-hydrolysed } \\
\text { control }\end{array}$ & Corrected value & $\begin{array}{c}10^{15} \times \text { DNA } \\
\text { content } \\
\text { per cell }(\mathrm{g})\end{array}$ \\
\hline Stationary phase bacteria & $72 \cdot 6 \pm 3.7(33)^{*}$ & $15.5 \pm 1.0(15)$ & $57 \cdot 1 \pm 3 \cdot 8$ & $7 \cdot 8 \pm 0.5$ \\
\hline $\begin{array}{l}\text { Bacteroids from } \\
\text { 2I-day-old Pisum sativum }\end{array}$ & $411 \cdot 0 \pm 19 \cdot 6(20)$ & $84 \cdot 4 \pm 13 \cdot 5(5)$ & $326 \cdot 6 \pm 23 \cdot 8$ & $44 \cdot 4 \pm 3 \cdot 3$ \\
\hline Human G-chromosome & $733 \cdot 0 \pm 26 \cdot 4(9)$ & ND & $733 \cdot 0 \pm 26 \cdot 4$ & $100 \dagger$ \\
\hline
\end{tabular}

ND, Not detectable.

* Values are given \pm S.E.M. with the number of determinations in parentheses.

$\dagger$ According to Mendelsohn \& Mayall (I974).

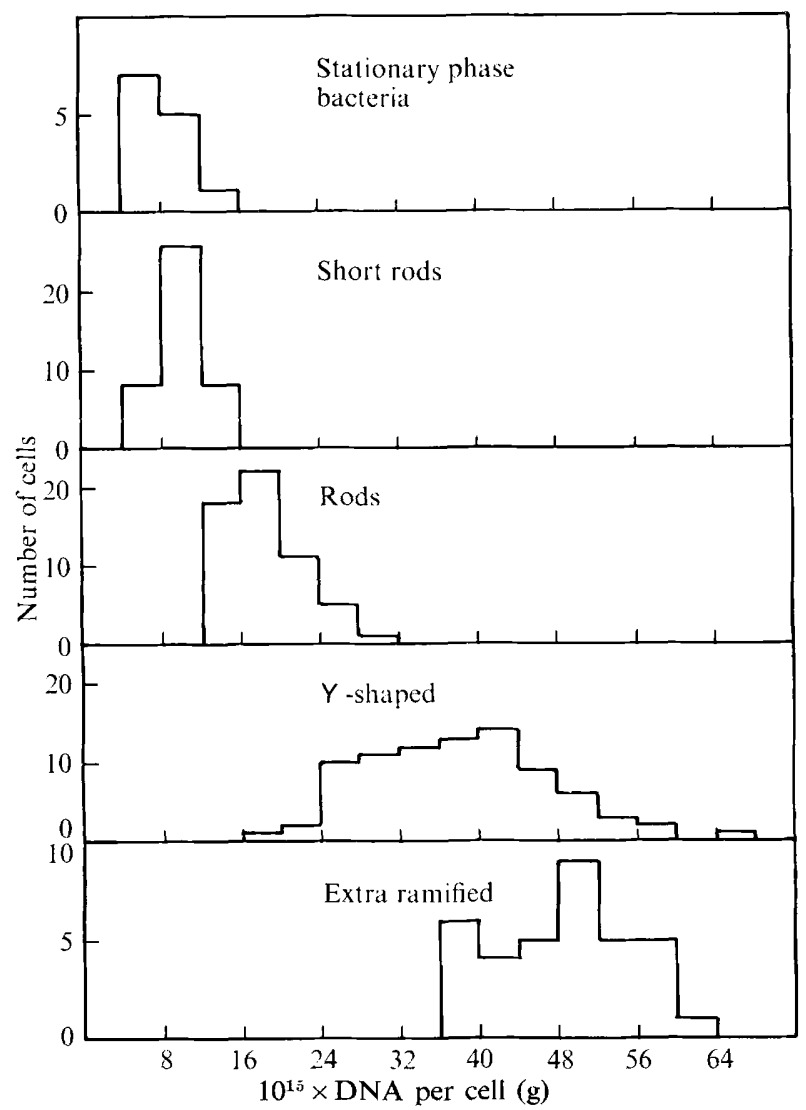

Fig. I. Histograms showing the DNA content distribution of the different morphological classes of bacteroids and bacteria of $R$. leguminosarum. Bacteria were grown as in Methods. Bacteroids were isolated from nodules of 16 -day-old Pisum sativum plants. Feulgen-stained microscope slides were prepared and the DNA content of randomly chosen cells was measured (as in Table I). The number of cells measured for each morphological class of bacteroids is not necessarily in accordance with the relative frequency of that class in the preparation. 
plants are given in Table $\mathrm{I}$. The bacteria as well as the bacteroids appeared to contain an appreciable amount of material which was stained by Schiff's reagent without the preceding hydrochloric acid treatment (Io to $20 \%$ of the 'hydrolysed' value). With the filter combination used no autofluorescence emission was detectable in preparations not submitted to hydrolysis and Schiff staining. With non-hydrolysed bacteroids of $R$. leguminosarum strain PRE for example, the $Y$ shape was dimly visible on a dark background under the fluorescence microscope. In a hydrolysed and stained preparation, the DNA was visible as more or less discrete spots and these occupied the largest part of the cell.

The bacteroids of $R$. leguminosarum strain PRE are not homogeneous in shape and size. They may be classified as small rods, rods, normal $Y$ shapes and extra ramified particles, although a sharp distinction is not possible because of transitory forms. The ramified forms are larger than the rods.

The average DNA content of a number of randomly chosen cells is given in Table I. These results were essentially the same as those of Reijnders et al. (1975). The DNA content appeared to differ between different size classes, as is illustrated by the histograms in Fig. I. Clearly, the more ramified the structures, the higher the DNA content. Microscopic examination of preparations of nodules of several ages showed that the youngest cells (I4 days) contained relatively more (small) rods, while from 2I days onward the normal $Y$ shapes were mainly found. The $Y$ shapes of different ages up to 42 days did not appear to differ in DNA content. Thus, the age of the bacteroids appears to determine their form, while a correlation was found between the form and DNA content of the cell. It should be noted that the short rods from nodules contain on average slightly more DNA than stationary phase bacteria. This probably implies that the short rods should be regarded as growing cells replicating their DNA.

Theoretically, the fluorescence emission may be reduced by self-absorption of the emitted light in regions of high DNA concentration, so we examined the absorbance of the bacteria at $560 \mathrm{~nm}$. Absorbance cytophotometry was performed on photographs taken at $560 \mathrm{~nm}$, as described by van der Ploeg et al. (1974), to determine local stain intensity in bacteria and bacteroids. The local absorbance was always below 0.I. Prenna et al. (1974) have shown that there is no appreciable absorption of fluorescent light in such cases and the measured fluorescent light intensities are thus linearly related to the amount of fluorescent stain present and can be used directly to calculate the amount of DNA.

\section{Measurement of the DNA contents of other Rhizobium species}

Next we investigated whether the increase in DNA content per cell accompanying the bacteroid formation was peculiar to one species, by examining bacteria and bacteroids of different Rhizobium species in the same way. Bacteria were taken from broth cultures just after they had reached the stationary phase of growth and bacteroids were isolated I week after the first nodules were visible (i.e. about 3 weeks after planting and inoculation). The DNA content of the bacteroids was greater than that of the bacteria in all species tested except $R$. ' cowpea' strain CB756, on Vigna unguiculata, in which they were the same (Table 2).

Our method allows an independent determination of the DNA content of individual cells. Since the cytofluorometrical measurements show an increase in DNA content per cell during bacteroid formation in nearly all species tested, the non-viability of bacteroids does not seem to be caused by a loss of DNA. In fact it seems even probable that the whole genome is multiplied in some cases, as in R. leguminosarum strain PRE for which Reijnders et al. (1975) found no significant difference in composition between the DNA of bacteria and bacteroids.

Our conclusion that the transition of bacteria into the bacteroid form is not accompanied by a loss of DNA does not agree with the findings of other authors (Bergersen, I958; Dilworth \& Williams, 1967; Sutton, 1974). Though the DNA content of strain NZP2037 bacteria reported here agrees well with the value given by Sutton (1974), there is a large discrepancy between the values reported for the corresponding bacteroids from Lotus; we 
Table 2. Mean DNA content per cell of different species of Rhizobium in bacteroids and in broth-cultured bacteria

\begin{tabular}{|c|c|c|c|c|}
\hline \multirow[b]{2}{*}{ Species } & \multirow[b]{2}{*}{ Strain no. and host } & \multicolumn{2}{|c|}{$\mathrm{IO}^{\mathrm{I} \overline{ }} \times \mathrm{DNA}$ content per cell $(\mathrm{g})$} & \multirow{2}{*}{$\begin{array}{c}\text { Increase } \\
\text { factor }\end{array}$} \\
\hline & & Bacteria & Bacteroids & \\
\hline R. leguminosarum & PRE; Pisum sativum (var. Rondo) & $7 \cdot 8 \pm 0.5(33)^{*}$ & $44 \cdot 4 \pm 3 \cdot 3(20)$ & $5 \cdot 7$ \\
\hline R. meliloti & $\begin{array}{l}\text { KAI } 45 \text {; Medicago sativa } \\
\text { (var. du Puits) }\end{array}$ & $10 \cdot 9 \pm I \cdot 8(24)$ & $46 \cdot 2 \pm 2 \cdot 8(30)$ & $4 \cdot 3$ \\
\hline R. japonicum & $\begin{array}{l}\text { WA107; Glycine max (var. } \\
\text { Hawkey) }\end{array}$ & $9 \cdot I \pm 0 \cdot 3(42)$ & $19 \cdot 3 \pm I \cdot 3(22)$ & $2 \cdot I$ \\
\hline R. lupini & GK82; Ornithophus sativus & $7 \cdot 2 \pm 0 \cdot 3(23)$ & $13.7 \pm 0.6(23)$ & $\mathrm{I} \cdot 9$ \\
\hline R. trifolii & $\begin{array}{l}\text { wK8; Trifolium pratense (var. } \\
\text { Kühn) }\end{array}$ & II $3 \pm 0 \cdot 7(24)$ & $87 \cdot 6 \pm 4 \cdot 0(22)$ & $7 \cdot 8$ \\
\hline R. phaseoli & $\begin{array}{l}\text { KA47; Phaseolus vulgaris } \\
\text { (var. Walcherse witte) }\end{array}$ & $14 \cdot 0 \pm I \cdot 2(15)$ & $20 \cdot 3 \pm I \cdot 4(23)$ & $\mathrm{I} \cdot 5$ \\
\hline R. 'cowpea' & $\begin{array}{l}\text { CB756; Vigna unguiculata } \\
\text { Walp (var. Blackeye Early } \\
\text { Ramshorn) }\end{array}$ & $7 \cdot 1 \pm 0 \cdot 5(20)$ & $7 \cdot 1 \pm 0.6(20)$ & $I \cdot 0$ \\
\hline$R$. 'loti' & $\begin{array}{l}\text { NZP2037; Lotus corniculatus } \times \\
\text { Lotus pedunculatus } \dagger\end{array}$ & $10 \cdot 7 \pm 0.5(20)$ & $3 I \cdot 6 \pm I \cdot 6(20)$ & $3 \cdot 0$ \\
\hline
\end{tabular}

cannot explain this at the present. The DNA content of bacteroids of $R$. lupini reported here agrees well with the result of Dilworth \& Williams (1967). However, these authors did not compare the bacteroids with stationary phase broth-cultured bacteria but with bacteria isolated from lengths of roots. The value that they reported for these bacteria might be high because of possible contamination of the preparations with material of plant origin (compare Table 2 and Dilworth \& Williams, I967).

\section{Influence of host plant on DNA content of bacteroids}

When different strains of $R$. leguminosarum (which give efficient nitrogen-fixing symbiosis) were inoculated on peas, they all produced bacteroids with 3 to 8 times more DNA than the corresponding free-living bacteria. There was also a correlation between the size of the bacteroids and their DNA contents. The bacteroids of these strains from nodules produced after inoculation on Vicia faba were all smaller and contained less DNA than those from pea nodules. This again indicates that the DNA content is mainly determined by the size of the bacteroid.

The plant host thus appears to infiuence the development of the bacteroid and its DNA content. We suggest that the plant does not actually stimulate the bacteroid to multiply its DNA, but rather that the plant exerts an influence resulting in an impaired cell division. The normal DNA replication takes place and the size of the cell increases but the actual septum formation before cell division does not occur. Under certain circumstances similar phenomena of bacteroid formation can be observed in vitro (Jordan \& Coulter, 1965; Fred, Baldwin \& McCoy, 1932). Bacteroid formation may thus be regarded as a form of growth comparable to the formation of filaments of certain bacteria (Slater \& Schaechter, 1974), in which cells grow and multiply their DNA in the absence of cell division. Our results suggest a correlation between the size of the cell as seen under the microscope and its DNA content. In this respect it may be meaningful that the DNA/protein ratio in bacteria and bacteroids of $R$. leguminosarum remains relatively constant (Reijnders et al., 1975), as is also observed in artificial filament formation (Slater \& Schaechter, 1974). 
The authors gratefully acknowledge financial support from the Netherlands Foundation for Biological Research. We are grateful to Dr W. D. Sutton for preparing bacteria and bacteroids of strain NZP2037.

\section{REFERENCES}

BERGERSEN, F. J. (1958). The bacterial component of soybean root nodules; changes in respiratory activity, cell dry weight and nucleic acid content with increasing nodule age. Journal of General Microbiology 19, 31 2-323.

Bergersen, F. J. (1974). The formation and function of bacteroids. In The Biology of Nitrogen Fixation, pp. 473-498. Edited by A. Quispel. Amsterdam \& Oxford: North-Holland Publishing Company.

BöHm, N. \& SANdritter, W. (1975). DNA in human tumours: a cytophotometric study. In Current Topics in Pathology, vol. 6o, pp. 15I-2 I9. Edited by E. Gründman \& W. H. Kirsten. Berlin \& Heidelberg: Springer Verlag.

Bosman, F. T. (1976). DNA cytophotometry of human metaphase chromosomes. Ph.D. thesis, University of Leiden, The Netherlands.

Bosman, F. T., van der Ploeg, M., Schaberg, A. \& VAN DUIJN, P. (1975). Chromosome preparations of human blood lymphocytes-evaluation of techniques. Genetica $45,425-433$.

Bosman, F. T., van der Ploeg, M., van Duijn, P. \& Schaberg, A. (1977). Photometric determination of the DNA distribution in the 24 human chromosomes. Experimental Cell Research 105, 3OI-3II.

Burton, K. (1968). Determination of DNA concentration with diphenylamine. Methods in Enzymology I2 B I 63-166.

Dilworth, M. J. \& Williams, D. C. (I 967). Nucleic acid changes in bacteroids of Rhizobium lupini during nodule development. Journal of General Microbiology 48, 3 I-36.

DuiJndam, W. A. L. (1975). Cytochemical investigations on the Feulgen-Schiff reaction for DNA. Ph.D. thesis, University of Leiden, The Netherlands.

Fred, E. B., Baldwin, J. L. \& McCoy, E. (I932). Root Nodule Bacteria and Leguminous Plants, University of Wisconsin studies. Madison, U.S.A: University of Wisconsin.
GraumanN, W. (I953). Zur Standardisierung des Schiffschen Reagenz. Zeitschrift für wissenschaftliche Mikroskopie und für mikroskopische Technik 6r, $225-226$.

Jordan, D. C. \& Coulter, W. H. (I965). On the cytology and synthetic capacities of naturally and artificially produced bacteroids of Rhizobium leguminosarum. Canadian Journal of Microbiology II, 709-720.

Mendelsohn, M. L. \& Mayall, B. H. (I974). Chromosome jdentification by image analysis and quantitative cytochemistry. In Human Chromosome Methodology, and edn, pp. 3 I I-346. Edited by J. J. Yunis. New York \& London: Academic Press.

Prenna, G., Leiva, S. \& Mazzini, G. (I974). Quantitation of DNA by cytofluorometry of the conventional Feulgen reaction. Histochemical Journal 6, 467-489.

Reijnders, L., VisSer, L., Aalbers, A. M. J., VAN Kammen, A. \& Houwers, A. (I975). A comparison of DNA from free living and endosymbiotic Rhizobium leguminosarum (strain PRE). Biochimica et biophysica acta 4I4, 206-2 I6.

Slater, M. \& Schaechter, M. (1974). Control of cell division in bacteria. Bacteriological Reviews 38, 199-22I.

SutTon, W. D. (1974). Some features of the DNA of Rhizobium bacteroids and bacteria. Biochimica et biophysica acta 366, I-IO.

van Der Ploeg, M., van Duijn, P. \& Ploem, J. S. (1974). High-resolution scanning-densitometry of photographic negatives of human metaphase chromosomes. I. Instrumentation. Histochemistry 42, 9-29.

vaN der Ploeg, M., Vossepoel, A. M., van Duijn, P. \& Bosman, F. T. (1977). High-resolution scanning-densitometry of photographic negatives of human metaphase chromosomes. III. Determination of fluorescence emission intensities. Histochemistry 5I, 269-29I. 